Managing Food Hygiene 


\section{Related Macmillan Titles}

The New Catering Repertoire H. L. Cracknell and G. Nobis

Volume 1 Aide-Mémoire du Chef

Volume 2 Aide-Mémoire du Restaurateur et Sommelier

Practical Professional Catering H. L. Cracknell, G. Nobis and

R. Kaufmann

Practical Professional Cookery H. L. Cracknell and R. Kaufmann

Practical Professional Gastronomy H. L. Cracknell and G. Nobis

Financial Management for the Hospitality, Tourism and Leisure Industries

Sally Messenger and Humphrey Shaw

Hospitality Management: Case Studies

Sally Messenger and Humphrey Shaw

Healthy Eating: A Guide for Chefs and Caterers Rob Silverstone

Food Hygiene for Food Handlers Jill Trickett

Published with the Hotel and Catering Training Company:

Food Preparation and Cooking Levels 1 and 2 Roy Hayter

Food and Drink Service Levels 1 and 2 Roy Hayter

Safety in Catering Roy Hayter

Customercraft: Keeping the Customer Satisfied Roy Apps

Please write to The Sales Department, Macmillan Press, Houndmills, Basingstoke, Hants RG21 6XS, for details of other Macmillan textbooks and the current Vocational Education catalogue. 


\title{
Managing Food Hygiene
}

\author{
Second Edition
}

Nicholas Johns, BSc, PhD, Cert. Ed., Dip. FE, AMHCIMA Reader and Director of Research

The Hotel School

City College Norwich 
(C) Nicholas Johns 1991, 1995

All rights reserved. No reproduction, copy or transmission of this publication may be made without written permission.

No paragraph of this publication may be reproduced, copied or transmitted save with written permission or in accordance with the provisions of the Copyright, Designs and Patents Act 1988, or under the terms of any licence permitting limited copying issued by the Copyright Licensing Agency, 90 Tottenham Court Road, London W1P 9HE.

Any person who does any unauthorized act in relation to this publication may be liable to criminal prosecution and civil claims for damages.

First edition 1991

Reprinted 1993

Second edition 1995

Published by

MACMILLAN PRESS LTD

Houndmills, Basingstoke, Hampshire RG21 6XS

and London

Companies and representatives

throughout the world

ISBN 978-0-333-65117-9 ISBN 978-1-349-13953-8 (eBook)

DOI 10.1007/978-1-349-13953-8

A catalogue record for this book is available from the British Library.

$\begin{array}{llllllllll}10 & 9 & 8 & 7 & 6 & 5 & 4 & 3 & 2 & 1\end{array}$

$\begin{array}{llllllllll}04 & 03 & 02 & 01 & 00 & 99 & 98 & 97 & 96 & 95\end{array}$

Copy-edited and typeset by Povey-Edmondson

Okehampton and Rochdale, England 
To the memory of Michael Allen, FRCS, who gave me much help and encouragement for this book but sadly did not live to see its publication 


\section{Contents}

Preface to the Second Edition

xiii

Introduction

xiv

Acknowledgements

xvi

1 Food Hygiene and General Hygiene

Introduction

Types of Food Contamination

Types of Pathogen

Relative Importance of Bacterial Food-borne Illness 6

Preventing Food Contamination

Preventing Transfer of Contaminants $\quad 9$

Preventing Bacterial Growth $\quad 11$

Destroying Bacteria 16

Summary - Food Hygiene 19

$\begin{array}{ll}\text { General Hygiene } & 19\end{array}$

The Cleaning Process $\quad 21$

Detergents $\quad 23$

Disinfectants 26

Summary - Cleaning $\quad 28$

Pests and Pest Control $\quad 29$

Rodents $\quad 29$

Crawling Insects $\quad 33$

Flying Insects $\quad 36$

Control of Flying Insects $\quad 37$

Stored Product Insects $\quad 39$

Ecological Control $\quad 39$

Summary - Pest Control $\quad 40$

2 Food-borne Illness, Microorganisms and Parasites

Introduction $\quad 41$

$\begin{array}{lr}\text { Epidemiology } & 42\end{array}$

Investigating an Outbreak $\quad 42$

$\begin{array}{ll}\text { Bacteria } & 43\end{array}$

Bacterial Reproduction $\quad 47$

$\begin{array}{ll}\text { Identification of Bacteria } & 47\end{array}$ 
Bacteria Which Cause Food-borne Illness $\quad 50$

$\begin{array}{ll}\text { Viruses } & 61\end{array}$

Distribution of Bacterial and Viral Food-borne Illness 63

Summary - Bacterial Food-borne Illness 65

Parasites $\quad 66$

$\begin{array}{ll}\text { Protozoa } & 67\end{array}$

$\begin{array}{ll}\text { Roundworms } & 68\end{array}$

$\begin{array}{ll}\text { Flatworms } & 69\end{array}$

$\begin{array}{ll}\text { Moulds and Yeasts } & 70\end{array}$

$\begin{array}{ll}\text { Summary - Microorganisms and Parasites } & 74\end{array}$

3 Food Commodities, Food Processing and Cooking

Introduction $\quad 75$

$\begin{array}{ll}\text { Food Commodities } & 76\end{array}$

Preparation of Meat Carcasses $\quad 77$

Machine Recovered Meat (MRM) $\quad 78$

$\begin{array}{ll}\text { Slaughterhouse Controls } & 78\end{array}$

$\begin{array}{ll}\text { Game } & 79\end{array}$

Raw Vegetables and Fruit $\quad 80$

Cereals and Pulse Foods $\quad 81$

Dairy Products $\quad 82$

Dairy Controls $\quad 84$

$\begin{array}{lr}\text { Fish } & 85\end{array}$

Shellfish $\quad 86$

Herbs and Spices $\quad 89$

$\begin{array}{lr}\text { Beverages } & 89\end{array}$

Water and Ice $\quad 91$

Processed and Preserved Foods $\quad 92$

Food Spoilage $\quad 92$

Food Preservation Techniques 94

Inhibiting Microbial Growth 94

Lowering the Storage Temperature 95

Preservation by Lowering Water Activity 98

$\begin{array}{lr}\text { Salted Foods } & 100\end{array}$

$\begin{array}{ll}\text { Sugar and Alcohol Preserves } & 100\end{array}$

Preservation by Changing Oxygen Availability 100

$\begin{array}{ll}\text { Preservation by Lowering the } \mathrm{pH} & 101\end{array}$

$\begin{array}{ll}\text { Preservation by Adding Chemicals } & 101\end{array}$

Destroying Microorganisms in Food 102

Problems with Canned Goods 103

Summary - Commodities and Preserved Foods 105

$\begin{array}{ll}\text { Cooking Methods } & 105\end{array}$

Summary - Cooking Methods $\quad 111$

$\begin{array}{ll}\text { Hot-holding Techniques } & 112\end{array}$ 
Summary - Hot-holding Techniques

\section{Food Hygiene and the Law}

Introduction

Types of Law

Sources of Law

Primary and Secondary Legislation $\quad 117$

$\begin{array}{ll}\text { Interpretation of Legislation } & 117\end{array}$

European Community Legislation 118

Influence of the WHO $\quad 119$

The Structure of Food Hygiene Law in Britain $\quad 119$

The Food Safety Act, $1990 \quad 120$

The National Health Service (Amendment) Act, $1986 \quad 129$

The Food Safety (General Food Hygiene) Regulations, $1995 \quad 129$

How Food Hygiene Law is Enforced 136

Registration 137

Detection of Offences 137

$\begin{array}{ll}\text { Equipment } & 139\end{array}$

Inspection Procedure $\quad 139$

Legal Action $\quad 141$

Prohibition and Destruction Orders 141

Prosecution $\quad 142$

Magistrates' Court $\quad 143$

Crown Court 143

Appeal 144

Scottish Courts 144

Other Legislation Relevant to Food Hygiene 145

Regulations Affecting Specific Foods $\quad 145$

Food Packaging Controls $\quad 147$

Legislation Overlapping with Food Hygiene Provision 147

$\begin{array}{ll}\text { Codes of Practice } & 150\end{array}$

$\begin{array}{ll}\text { British Standards } & 150\end{array}$

Other Publications 151

Summary - Food Hygiene Law 151

\section{Food Hygiene and the Management of Premises}

Introduction 153

Planning and Design 154

$\begin{array}{ll}\text { Planning Considerations } & 155\end{array}$

Planning of Work-centres and Amenities 161

Subdivision and Separation 163

Detailed Design Considerations 165

Services 171

Summary - Planning and Design 175 
Upkeep Operations: Maintenance, Cleaning and Pest Control 176 $\begin{array}{ll}\text { Strategies } & 176\end{array}$

$\begin{array}{ll}\text { Preventive Versus Corrective Strategies } & 179\end{array}$

$\begin{array}{ll}\text { Cost Effectiveness } & 179\end{array}$

$\begin{array}{ll}\text { Statutory Requirements } & 180\end{array}$

$\begin{array}{ll}\text { Clients' Operating Needs } & 180\end{array}$

Reducing the Incidence of Running Maintenance 180

$\begin{array}{ll}\text { Work Versus Inspection } & 180\end{array}$

Maintenance, Cleaning and Pest Control Cycles 182

Frequency and Standards $\quad 183$

In-house Versus Outside Contract Work 186

Selection of Specialist Contractors 186

Co-operation with Environmental Health Departments 188

$\begin{array}{ll}\text { Co-operation with the Client } & 188\end{array}$

Management Systems for Cleaning and Maintenance 189

Designing a Cleaning/Maintenance System 189

$\begin{array}{ll}\text { Schedules } & 189\end{array}$

Job Cards $\quad 191$

Task Record Sheets 193

Summary - Cleaning, Maintenance and Pest Control 194

6 Food Hygiene and the Management of Plant and Equipment

$\begin{array}{ll}\text { Introduction } & 195\end{array}$

Legal Aspects 195

Contamination Levels of Plant/Equipment 196

$\begin{array}{ll}\text { Keeping Plant and Equipment Clean } & 197\end{array}$

$\begin{array}{ll}\text { Cleaning Methods } & 198\end{array}$

Maintenance $\quad 200$

Selection of Equipment $\quad 201$

Equipment Used for Handling or Holding Food 202

Time/Temperature Aspects $\quad 209$

Location of Equipment $\quad 211$

Monitoring and Control $\quad 212$

Summary - Equipment Used for Processing or Holding Food 214

Other Equipment Involved in Food Hygiene 215

Equipment for the Hygiene of Premises 215

$\begin{array}{ll}\text { Mechanical Cleaning Equipment } & 217\end{array}$

Equipment for Cleaning Utensils, etc. 222

Equipment for Personal Hygiene 223

Summary - Hygiene Equipment 226

7 Food Hygiene and the Management of Personnel

$\begin{array}{ll}\text { Introduction } & 227\end{array}$

Standards of Personal Health and Hygiene 228 
Protective Clothing 231

Achieving Staff Hygiene Standards 234

Monitoring Health and Hygiene 235

Staff Selection $\quad 235$

Summary - Personnel Selection 243

Training and Education $\quad 243$

Teaching and Learning 244

Personal Qualities of the Trainer 245

Training Strategies 245

The Training Cycle 246

Summary - Training 256

Motivating Staff $\quad 257$

Summary - Motivation $\quad 260$

8 Food Hygiene and Process Management

Introduction $\quad 262$

Defining the System 265

Planning the Menu 267

Planning the Production Process 271

Analyzing the Process 271

Avoiding Storage and Holding Risks 278

Managing the Operations $\quad 279$

Summary - Process Management 291

9 Food Hygiene Strategy and Policy

Introduction 293

The '4Ps' Approach 294

HACCP 295

Hazard Analysis 295

Identifying and Classifying Hazards 297

Rationalization of Hazards 301

Residual Hazards $\quad 302$

Critical Control Points 303

Documentation $\quad 307$

$\begin{array}{ll}\text { Training } & 309\end{array}$

Other Applications of HACCP 309

Summary - How to Implement HACCP 312

Food Hygiene Policies 313

Summary - Food Hygiene Policies 317

Strategy and Food Hygiene $\quad 318$

Productivity Strategies $\quad 320$

Summary - Strategy and Food Hygiene 322 
xii Contents

$\begin{array}{ll}\text { Answers to Study Examples } & 323\end{array}$

$\begin{array}{ll}\text { Glossary } & 336\end{array}$

$\begin{array}{ll}\text { Bibliography } & 345\end{array}$

$\begin{array}{lr}\text { Further Reading } & 350\end{array}$

$\begin{array}{ll}\text { Index } & 352\end{array}$ 


\section{Preface to the Second Edition}

Since the first edition of this book, the UK has adopted a number of European Directives aimed at harmonizing food hygiene legislation between the member states. These Directives have subsequently come into force as hygiene regulations for specific areas of the food industry such as meat or egg production. At the same time the British Government has been concerned to deregulate the food industry. In food hygiene terms this has meant two separate thrusts. On the one hand, hygiene legislation has been consolidated to bring out general 'horizontal' principles applicable to the whole food industry; these have highlighted the specific 'vertical' requirements of a few food manufacturing sectors. On the other hand, new legislation and codes of practice emphasize the responsibility of the food handler to assess risks and to maintain systems. The Hazard Analysis/ Critical Control Point (HACCP) approach is recommended as a basis for both the management and inspection of food processes.

The legislative changes of recent years are fully detailed and discussed in this new edition of Managing Food Hygiene. However, developments at Government level and within the food authorities reflect thinking that have been a feature of the book from the outset. In this new updated edition this aspect is maintained and enhanced, providing students and practitioners with a firm basis of knowledge and skills for tackling this important area of product safety. 
Managing Food Hygiene is intended for management students and managers in the hospitality, catering and retail industries. It explains the problems of food hygiene and discusses how they may be tackled from an operational management point of view. It is designed to function as a textbook for coursework or self-study, as well as being a practical handbook for use at work. The content has been designed to meet the requirements of advanced certificate and diploma courses offered by the IEHO, RSH and RIPHH. The first three chapters are devoted to scientific and technical aspects of food hygiene and cover general hygiene, food microbiology, epidemiology and food technology. Chapter 4 is concerned with the law. Four principal areas of management concern are discussed, in Chapters 5-8 respectively: premises, plant/equipment, personnel and process. Chapter 9 describes how food hygiene is related to policy and strategy in operational management.

An important aim of such courses is to prepare managers to train their own staff. For this reason the section on training in Chapter 7: Food Hygiene and the Management of Personnel is especially detailed, making the book a useful reference source for those who wish to design and deliver hygiene courses.

Managing Food Hygiene will also be a valuable textbook for courses in hospitality, catering and retail management, i.e. degree and BTEC HND courses. The sections dealing with epidemiology, food technology and especially law have been brought up to date by means of an extensive literature search. The book deals with topical issues such as Listeria, BSE and machine recovered meat and explains their relevance to food hygiene management. The structure and influence of the 1990 Food Safety Act and its subsidiary legislation are also discussed.

In addition to this background knowledge, Managing Food Hygiene describes what must be done to maintain food safety within food production and sales operations. Uniquely it goes one stage further, illustrating the management processes which are required to support such action. Chapters 5-8 discuss in detail the operational management techniques which will undoubtedly be needed if systems such as HACCP (described in detail in Chapter 9) are to be widely adopted by the British hospitality industry.

The inclusion of management material in a book of this type will aid integration of the subject into management degree and Higher National Diploma courses. It may also point the way to curriculum development in this area. This integrated management material should also help to make Managing Food Hygiene an indispensable handbook for practising managers in the industry. 


\section{Using this book}

Managing Food Hygiene is designed for self-study, reference, or for use as a textbook. The following points should be borne in mind.

In order to facilitate self study the book has been laid out in sections within chapters. Key words are presented in bold type to emphasize their importance and to aid learning. A glossary is provided at the end, to which the student is urged to refer. Throughout the book there are also short questions, to test comprehension. Students should keep a pencil and paper handy as they study, and should attempt to write down the answer to each question before proceeding through the section. The answer or explanation to each question is incorporated into the text immediately following it. In order to encourage the glossary habit, some of the questions ask the meaning of technical terms. The first two of these refer the student to the glossary.

Each chapter also contains three Study Examples, mostly located at or near the end of sections. Students should allow about 20-30 minutes for answering these examples and again it is a good idea to write the answers down clearly and to check them with the correct solutions. These are given at the back of the book.

Reference use is aided by a comprehensive index. Each section of the book is structured independently, to permit easy reference. However, some aspects require previous knowledge. For example, it may not be possible to fully understand Critical Control Points (Chapter 9) without previously learning about $\mathrm{D}$ and $\mathrm{z}$ values for bacterial destruction (Chapter 1). The text is crossreferenced to make this easier, but the reader should also make as much use as possible of the glossary and index.

Textbooks are often structured to match the syllabus with which they are intended to be used. This of course cannot be the case with Managing Food Hygiene, which is designed to meet the needs of several different syllabuses and teaching styles. Students who wish to use this book as a textbook should first draw up a list of the syllabus items they are required to learn. They should then look these up systematically, making notes as they go. It will frequently be necessary to transfer between chapters. For instance, details of insect and rodent pests are presented in Chapter 1, while the management of pest control is discussed in Chapter 5. Some syllabuses will require the student to put all this information together into one single package of notes. This may seem awkward at first, but it occurs to some extent in every book. The process of making and reorganizing notes is itself a very useful learning process. 


\section{Acknowledgements}

All books are compilations of the work and experiences of others, and this is no exception. The list of references at the end bears witness to a heavy debt, and gratitude is owing to all those friends, colleagues and students who contributed ideas, read my work, and by discussion helped shape my ideas. Special mention should go to John Staples, Carolyn Owen, Philip Tyas and Jim Jones.

It is impossible to put together such a heterogeneous body of material without the help of librarians. I am deeply indebted to all the library staff at City College Norwich for their endless patience. Mention should also be made of the library staff of Colman Foods Ltd., the Institute of Food Research and the Norfolk and Norwich Hospital, who were kind and helpful whenever I needed them.

Thanks are due to the Computer Services Section at City College Norwich for their help and indulgence with keying in text and keeping the wheels rolling so that everything could be processed, copied and printed.

Finally and most importantly I must thank my wife Helen for tea, sympathy and space during the interminable working hours; my daughter Theresa for reading the typescript and compiling the glossary; and everyone else at home for their patience and forbearance.

Nicholas JoHnS

The author and publishers wish to thank the following who have kindly given permission for the use of copyright material:

Elsevier Science Publishers Ltd. for Fig. 8.4 from Milson \& Kirk, 'The caterer as a process engineer', in Advances in Catering Technology, ed. G. Glew, Applied Science Publishers, 1979.

The Institution of Environmental Health Offices for an extract from R. A. E. North, 'Food contact surface disinfectants: additional criteria for selection', Environmental Health, 88(1), pp. 10-14; Fig. 2.5, 'Food epidemiology: gastro-intestinal infections, 1977-1985', Environmental Health, 94, 1986; Fig. 3.1, McDowell et al., 'Bacterial microflora of chill-stored beef carcasses', Environmental Health, 94(3); Figs 5.2 and 5.3, Mendes, Lynch and Stanley, 'A bacteriological survey of kitchens', Environmental Health, 86(10), 1978; and Fig. 5.10, R. P. Robinson, 'Ridding NHS hospitals of serious infestations', Environmental Health 95(1), 1987.

Stanley Thornes (Publishers) Ltd. for Fig. 6.6, adapted from D. M. Allen, Accommodation and Cleaning Services, Vol. 1, Fig. 47(b), Hutchinson, 1983.

The Talbot Adair Press for Fig. 7.5, from J. Adair, Training for Leadership, 1988.

Every effort has been made to trace all the copyright-holders, but if any have been inadvertently overlooked the publishers will be pleased to make the necessary arrangement at the first opportunity. 